\title{
Redefining Constructio Praegnans: On the Variation between Allative and Locative Expressions in Ancient Greek
}

\author{
Tatiana Nikitina ${ }^{\mathrm{a}}$ and Boris Maslov \\ a) LLACAN, CNRS \\ tavnik@gmail.com \\ b) University of Chicago \\ maslov@uchicago.edu
}

\begin{abstract}
In traditional Ancient Greek grammar, the term constructio praegnans refers to an apparent syntactic anomaly whereby the idea of motion is missing from either the verb or the prepositional phrase: a verb that does not express motion is combined with a directional prepositional phrase (e.g., 'slaughter into a container') or a motion verb combines with a static prepositional phrase describing a goal of motion (e.g., 'throw in the fire'). This study explores such usages in the period from Archaic to Classical Greek and argues against treating constructio praegnans as a unitary phenomenon. The seemingly aberrant combinations of the verb's meaning and the type of prepositional phrase are shown to be motivated by four independent factors: 1) lexical (some individual non-motion verbs select for a directional argument);2) aspectual (static encoding of endpoints is allowed with perfect participles); 3) the encoding of results with change of state verbs; and 4) the archaic use of static prepositional phrases in directional contexts (the goal argument of a motion verb is described by a static prepositional phrase). The four types of "pregnant" use are paralleled by different phenomena in other languages. Based on statistical analysis, they are also argued to undergo different kinds of diachronic development. Some of these developments, nevertheless, fall into a more general pattern: Ancient Greek gradually moves toward a more consistent use of specialized directional expressions to mark goals of motion, conforming increasingly to the "satellite-framed" type of motion encoding.
\end{abstract}

\section{Keywords}

Ancient Greek; motion verbs; prepositions; goals of motion; satellite-framed; Archaic Greek poetic style; aspect

\footnotetext{
*) For helpful feedback on our first draft, we thank participants of the PROIEL research seminar at the University of Oslo; special thanks are due to Dag Haug, Hanne Eckhoff, and Øyvind Strand. We are also grateful to the editors and the anonymous reviewers of the Journal of Greek Linguistics for their comments and suggestions. A preliminary discussion of some of the data treated here appeared in Maslov and Nikitina (2009).
} 


\section{Introduction}

In the parlance of students of Ancient Greek grammar, the term constructio praegnans - the "pregnant" construction-refers to constructions with two different types of mismatch between form and meaning (Kühner and Gerth 1898: 540-545; Smyth 1956: 368; Ruijgh 1994: 136; Skopeteas 2008b). In one, a goal of motion is encoded by a prepositional phrase that normally describes static locations, and the idea of motion is inferred from the verb. The construction expressing an object's motion (described by the verb) thus appears to be "pregnant" with an additional meaning: that of coming to rest at a certain location (described by the static prepositional phrase):

(1) hò d' en purì bálle thuēlás

he:NOM PRT in fire:DAT throw:IMPF.3SG offerings:ACC

'and he threw sacrificial offerings in the fire'

(Hom. Il. 9.220)

In the other type of constructio praegnans, a prepositional phrase that is normally used to encode spatial goals appears, unexpectedly, with a verb that does not seem to describe any motion (as if the verb were "pregnant" with an implicit motion component):

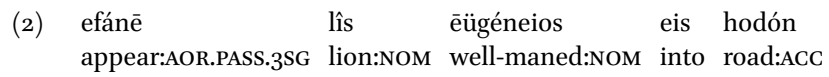

'A well-maned lion appeared on the road.' (literally, "into the road")

(Hom. Il. 15.275)

The two types presented in examples (1) and (2) are traditionally treatedexplicitly or implicitly_as different manifestations of the same underlying phenomenon. In Ancient Greek, the idea of directional motion is normally encoded in both the verb and the prepositional phrase; in the "pregnant" constructions, however, the explicit encoding is absent from one of the components: from the verb (as in (2)) or from the prepositional phrase (as in (1)).

Kühner and Gerth (1898: 540-542) praise the "pregnant" construction for its "imagistic brevity" ("malerische Kürze"), regarding it as an affectation especially characteristic of Homer ("eine Eigentümlichkeit der griechischen, namentlich der Homerischen Sprache”). They view the absence of a directional prepositional phrase or of a motion verb as a special device that requires the hearer or the reader to supply a missing piece of information: in (1), the offerings are cast into the fire, where they are supposed to remain (cf. Smyth 1956: 368); in (2), the lion becomes visible while moving into the road. In the spirit of the idealist tradition, Kühner and Gerth regard the widespread use of this construction as a testimony to a poetic faculty of the Greek mind $(540,544){ }^{1}$

1) The construction is similarly treated as a unitary phenomenon in Schwyzer (1950: 433-434), 
In this article, we contest the traditional view of constructio praegnans as a unitary phenomenon. We explore the use of the "pregnant" construction in the period from Archaic to Classical Greek and suggest that the attested examples fall into four distinct types of construction, which differ in conditions on their use and in their historical evolution. Our data is drawn from Thesaurus Linguae Graecae (http://www.tlg.uci.edu/); most searches were completed in Spring 2011. Table 1 lists the subcorpora used in this study, each characterized by a particular combination of genre and time period.

Table 1. Subcorpora of TLG used in this study

\begin{tabular}{lll}
\hline Subcorpus & Authors & Approx. time period \\
\hline Homeric Greek & Homer: the Iliad, the Odyssey & $8-7$ c. BCE \\
Archaic poetry & Hesiod to Bacchylides & $7-$ mid. 5 c. BCE \\
Attic tragedy & Aeschylus, Sophocles, Euripides & 5 c. BCE \\
Attic comedy & Aristophanes & late 5- early 4 c. BCE \\
Classical Greek prose & Herodotus, Thucydides, Xenophon & mid. 5-mid. 4 c. BCE \\
\hline
\end{tabular}

This article is organized as follows. In Section 2 we propose to distinguish between four types of usage that fall under the traditional rubric of constructio praegnans. We argue that these usages are subject to different restrictions and are paralleled by different phenomena in other languages. In Section 3 we present diachronic evidence indicating that the four types of "pregnant" construction undergo different kinds of change. In particular, we investigate the choice between the static prepositional phrase en + NP-dative 'in x' and the corresponding directional prepositional phrase eis + NP-accusative 'into $\mathrm{x}^{\prime 2}$ with seven verbs (bállō 'throw, cast', píptō 'fall', (kath)híemi 'throw (down)', hístēmi 'stand, set', títhèmi 'put, place', (kath)hízdō 'seat, sit down', (kath)hézomai 'sit down') across five historical subcorpora. Section 4 concludes the paper and discusses implications of our findings for the typology of motion expressions and the evolution of the Ancient Greek prepositional system.

\footnotetext{
who, however, does not use the term constructio praegnans; another departure from the traditional account is the assertion that the mismatch is rooted in the (putatively more permissive) use of plain cases predating the emergence of prepositions. Chantraine (1963: 101-104) briefly describes this phenomenon in Homer, offering no explanation. The discussion in Cooper (1998: 1155-1156, 1175; following Krüger's 1873 German original), which regards constructio praegnans as a kind of brachylogy (cf. Smyth 1956: 682-663), is also purely descriptive.

2) The form eis has a variant es; throughout the paper, we refer to eis as a shortcut, encompassing both variants. Similarly, we subsume under the form en the variants en, ení, ein, einí.
} 


\section{The Four Varieties of Constructio Praegnans}

\subsection{The Lexical Type: Directional Encoding with Verbs Not Implying Motion}

Our first type describes instances where a verb that does not seem to imply any motion combines with a directional prepositional phrase, illustrated above in (2). On closer inspection, it turns out that in the overwhelming majority of such examples, no variation is in fact attested in the encoding of the verb's argument, and there is no evidence for a competition between directional and static encoding.

As acknowledged in Kühner and Gerth (1898: 543) and Schwyzer (1950: 434), for verbs denoting acts of gathering and collecting-sullégō, sunageírō, halízdō, summignumi - combining with a directional prepositional phrase is the norm rather than the exception:

(3) Epeì dè periêlthen ho eniautós, sunêgeire stratiàn eis

after PRT go.round:AOR.3SG ART year:NOM gather:AOR.3SG army:ACC into

Babulôna

Babylon:ACC

'After the year was completed, he collected the army in Babylon.' (literally, "into Babylon")

(Xen. Cyr. 8.6.19)

The fact that certain "static" verbs regularly combine in Ancient Greek with directional, rather than static, prepositional phrases suggests that we are dealing with cross-linguistic differences in the argument structure of individual verbs, rather than with a construction specific to Greek. In particular, a verb that takes a directional argument in one language may be translated into other languages with verbs that either encode the corresponding argument by a static expression or simply do not take such an argument (in the latter case, they can still be modified by static locative phrases describing the location where the event takes place).

This type of variation is especially common with verbs that describe changes of state closely associated with changes of location. Individual verbs of this type may or may not take a directional argument, depending on the language. For example, certain "static" English verbs presupposing a non-realized possibility of motion, such as remain (at a location), leave (in the meaning of 'let remain'), forget (in the meaning of 'leave behind'), correspond to Finnish verbs with a directional (more precisely, illative) argument (Dahl 1987; Fong 1997).

We believe that many other combinations of change of state verbs with directional prepositional phrases in Ancient Greek instantiate the same phenomenon. Rather than being "augmented", in a specific construction, by a motion 
component, such verbs select, on an individual basis, a directional argument with a specific semantic role.

The verb ekleipo 'leave', for example, is commonly attested in what Kühner and Gerth describe as a "pregnant" meaning, in descriptions of motion (cf. LSJ, s.v. 3 for a similar interpretation):

(4) ebouleúonto eklipeîn tè̀n pólin es tà ákra tês deliberate:IMPF.MP.3PL leave:AOR.INF ART city:ACC into ART heights:ACC ART

Euboíês

Euboia:GEN

'They decreed to leave the city [and go] to the heights of Euboia.' (i.e. 'to leave the city for the heights of Euboia')

(Hdt. 6.100.2)

In this case, there is no competition between static and directional encoding. Instead, in this specialized meaning the Ancient Greek verb takes a directional argument, just as its English counterpart takes an argument introduced by the preposition for (see also Lys. 14.5, Xen. Anab. 1.2.24, 7.4.2). Both the Ancient Greek verb and its English equivalent combine with a source of motion (encoded as an object) and an endpoint of motion (encoded as a prepositional argument); the only difference is in the way the prepositional argument is introduced: by a directional preposition + case combination in Ancient Greek, but by a dative/benefactive preposition in English.

For some of the verbs that allow for both directional and static encoding, it is necessary to speak of polysemy, and to associate different meanings of the same verb with different argument structure. For example, the verb páreimi, attested with static prepositional phrases (or without a prepositional phrase) on the usual reading 'be present', appears with a directional argument on the reading 'arrive at' (LSJ, s. v. 5; cf. also Hdt. 6.1.1):

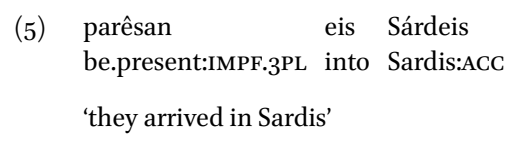

(Xen. Anab. 1.2.2)

The authoritative accounts in Kühner and Gerth (1898: 543) and Smyth (1956: 368 ) notwithstanding, such usage need not involve any "poetic brevity"; nor is it, properly speaking, "pregnant" or "elliptical". Rather, the verb can be viewed as encoding, on one of its readings, a change of state (from absent to present) that is commonly associated with a change of location. Unlike its English or German counterparts, the verb páreimi lexicalizes the change of location and takes a directional argument specifying the endpoint of associated motion. 
Similar behavior characterizes the verb phaino 'to appear', which is used with directional expressions on the meaning 'come to, move into'3 (cf. (2)). Other languages often display the same type of polysemy, associated with a difference in argument realization. For example, the Russian verb javljat'sja 'appear' can be used in the meaning 'come, arrive', and on that reading takes a directional argument:

(6) Sultan prikazal vizirju javit'sja $\mathrm{v}$ Konstantinopol' sultan ordered vizier appear:INF in Constantinople:ACC

'The sultan ordered the vizier to arrive in Constantinople.'

(A.S. Pushkin. Istorija Petra: Podgotovitel'nye teksty)

The lexical account captures the behavior of a number of verbs that are attested with directional arguments in Ancient Greek, but have no direct parallel in English or German.

Listed below are the verbs that have figured in discussions of the "pregnant" construction, in examples of "unexpected" directional combinations of eis 'into' with an accusative noun phrase. ${ }^{4}$ Crucially, the directional argument of such verbs is in many cases interpreted in an idiosyncratic way, and encodes a very specific semantic role that cannot be generalized to other verbs. Some of the verbs, moreover, are only capable of taking a directional argument on a very specific meaning, suggesting once again that we are dealing with the individual verb's lexical properties - its argument structure - rather than with a unitary construction that would allow entire classes of verbs to acquire a motion component by combining with a directional prepositional phrase.

- haliskomai 'to be captured; to fall into the hands of' (defective passive) The verb takes a directional argument referring to the captor or to the resulting location; static encoding is not attested for the corresponding argument:

(7) parà dè Hippokrátous toû Mindárou epistoléōs eis Lakedaímona from PRT H.:GEN ART M.:GEN secretary:GEN into Sparta:ACC

3) The use of phaínō with directional eis + accusative combinations is infrequent (Hdt. 4.14.3, epiphaínō with eis in Xen. Anab. 3.4.13). The same use is characteristic of paragígnomai 'to be beside', but also 'to come to' (marked as a special meaning in LSJ, s.v. II).

4) We do not consider cases of directional marking that are subject to an alternative interpretation. For example, Thuc. 6.4.1 is cited in Schwyzer (1950: 434) as "from there to Leontini joining the Chalcidians for a short time" (autóthen tô̂s Khalkideûsin es Leontínous olígon khrónon ksumpoliteúsas), where ksumpoliteúsas 'joining as a citizen' appears to govern the prepositional phrase es Leontínous 'to Leontini'. In fact, the missing main verb aphíketo 'he came', from an earlier part of the sentence, needs to be supplied in this clause. 
grámmata pemfthénta heálōsan eis Athếnas

letters:NOM send:PTCP.AOR.PASS.NOM.PL be.captured:AOR.3PL into Athens:ACC

'The letters sent by Hippocrates, Mindaros's secretary, to Sparta were captured [and ended up] in Athens.' (literally, "were captured into Athens")

(Xen. Hell. 1.1.23)

- sôzdō 'to save, rescue'

The verb is attested with directional expressions in the specialized meaning 'to bring someone safe (to a location)' and - in the passive- 'to escape; to come safe (to a location)' (LSJ, s.v. II.2); the directional argument encodes the place where safety is achieved:

(8) es Kurếnēn esốthēsan

into Cyrene:ACC save:AOR.PASS.3PL

'They were rescued [and brought] to Cyrene.'

(Thuc. 1.110.1)

- keîmai 'to lie, to be located' and its compounds

The verb hupékkeimai 'to be in safety' serves as a passive of hupektithemai 'to bring to safety' (cf. LSJ s.v.). The latter takes a directional argument in the Classical period (e.g., Lys. 2.34). The (unique) use of hupékkeimai with a directional eis + accusative combination is most likely due to analogy with hupektithemai:

(9) aûtis dè Salamìs perigínetai es tè̀n hēmîn

back PRT Salamis:NOM be.superior:PRES.MP.3SG into which:ACC us:DAT

hupékkeitai tékna te kaì gunaîkes

be.stowed.safe:PRES.MP.3SG children:NOM PRT and women:NOM

'Salamis [the island] will survive, to which our children and women have been brought to safety.'

(Hdt. 8.6o.2)

In (9), hèmin is the dative of agent, used with passive verbs. In some examples, where the verb does not have the passive meaning (and no dative of agent is present), hupékkeimai is used without a directional argument, and is modified by static locative phrases or adverbs. This difference suggests that in such cases the verb's argument structure corresponds to that of $k \hat{e} \hat{\imath}^{-}$ mai 'to lie, be located' (Hdt. 9.73.2, Thuc. 8.31.4, Isoc. 19.18).

Without the prefix, keimai 'to be located' is attested twice in a fixed idiomatic expression with a directional phrase 'into necessity' (cf. (10) and Hdt. 8.4):

(10) all' eis anágkēn keímeth'

but into necessity:ACC be.located:PRES.MP.IPL

'we have been brought into a disastrous condition'

(Eur. Iph.T. 620) 
This usage is also explained by the fact that keimai is used in the Classical period as a passive of tithèmi 'put, place', to describe a change of state. Rather than encoding an endpoint of motion, the directional expression introduces a non-spatial result; such results are regularly encoded by directional expressions (see Section 2.3).

Finally, anákeimai, in the specialized meaning 'to be referred to, depend on [a person]', demands a directional argument (LSJ, s.v. II). The expression does not describe literal motion, and represents, at the synchronic level, an idiosyncratic choice of argument encoding.

- spházdō 'to slaughter, sacrifice by cutting throat'

In a highly idiosyncratic usage, which is apparently associated with the sacrificial argot, this verb takes a directional argument specifying the receptacle into which the blood of the victim is collected, as in (11) (cf. examples in Xen. Anab. 2.2.10, Hdt. 4.62.3, 5.5.1, 7.113.2).

(11) hékaston tôn paídōn ésphazdon es tòn kratêra each:ACC ART children:GEN slay:IMPF.3PL into ART crater:ACC

'Each of the sons they slaughtered [so that their blood poured] into the crater.' (Hdt. 3.11.3)

In an extended usage, spházdō is also once attested, with a reflexive pronoun and a directional argument, in the meaning 'to slay (oneself) so as to collapse into' (Eur. Phoen. 1009).

- ephízdō / ephízdomai 'to set ashore, to bring down (to a place)'

This verb occurs twice in the Odyssey in what is commonly interpreted as constructio praegnans (Kühner and Gerth 1898: 543 ):

(12) es Libúēn $m^{\prime}$ epì nēòs ephéssato pontopóroio into Lybia:ACC me:ACC on ship:GEN set.upon:AOR.MID.3SG seafaring:GEN

'He brought me to Lybia on a seafaring ship.'

(Hom. Od. 14.295)

(13) toús m’ ekéleusa Púlonde katastêsai kaì ephéssai è eis ART me:ACC urge:AOR.1SG to.Pylos set.down:AOR.INF and set.upon:AOR.INF or into

Élida dîan

Elis:ACC heavenly:ACC

'I demanded that they bring me to Pylos or to heavenly Elis.'

(Hom. Od. 13.273-274)

As passage (13) demonstrates, the verb is a synonym of kathístèmi, which in the specialized meaning 'to bring to (a place)' takes a directional argument (cf. Hdt. 1.64). The compound ephízdō / ephízdomai similarly demands a directional phrase to encode the place of arrival (disembarking) in (12). 
- hairéo (passive) 'to be elected for an office'

This verb is similarly associated with a fixed, lexicalized interpretation of the directional argument; while the directional argument suggests a change of location, the verb does not entail physical motion. In (14), travel to Sparta is likely to follow the event of election, but may also be cancelled or infinitely delayed (cf. Aeschin. 3.100). ${ }^{5}$

(14) hēiréthē presbeutès eis Lakedaímona seize:AOR.PASS.3SG ambassador:NOM into Sparta:ACC

'He was elected an ambassador for Sparta.'

(Xen. Hell. 2.2.17)

In this case, parallels from other European languages can be adduced, cf. German Er wurde zum Gesandten nach Sparta gewählt (Kühner and Gerth 1898: 544).

\section{- hiketeúo 'to supplicate'}

This verb occurs twice in hexameter poetry in an apparent example of constructio praegnans. We are inclined to agree with Cunliffe (1963: 198, cf. Monro 1891: 190) in interpreting these passages as instantiating an older meaning 'come as a suppliant':

(15) es Pēlề hikéteuse kaì es Thétin argurópezdan

to Peleus:ACC approach.as.suppliant:AOR.3SG and to Thetis:ACC silver.footed:ACC

'He came as a suppliant to Peleus and silver-footed Thetis.'

(Hom. Il. 16.574; cf. Hes. Aspis 13)

This survey exhausts the list of verbs that are cited in examples of constructio praegnans with the directional preposition eis 'into'. Other types of prepositional phrase are also mentioned in discussions of "pregnant" constructions as illustrating the use of directional encoding "in place" of a static prepositional phrase. These prepositional phrases cannot, however, be accepted as solid evidence, since they are commonly used in descriptions of static locations, especially in idiomatic expressions.

5) Note that the absence of an article in (14) suggests that the prepositional phrase does not modify the noun presbeutès 'ambassador'. This is further confirmed by examples where the prepositional phrase is unambiguously related to the verb (Thuc. 8.64.2, Pl. Leges 754c). The noun apóstolos 'ambassador' also occurs with eis + accusative of city names (Hdt. 1.21.1, 5.38.1), but in this case the directional encoding is explained by the fact that apóstolos is a deverbal noun, derived from apostéllō 'to dispatch'.

6) What renders this interpretation particularly compelling is the derivation of hikétēs 'suppliant' from hikáno 'to arrive', which in Homer is often used in the context of arriving as a suppliant (Létoublon 1980). 
The ambiguous status of such prepositional phrases is acknowledged in dictionaries. For example, the combination of parà 'beside' with an accusative noun phrase is not restricted to the directional meaning 'to the side of'. It is commonly used in the static meaning 'beside, near' (LSJ, s.v. C.I.2), offering an easy solution to the alleged pregnant usage in (16).

(16) Tántalon dè parà toùs állous toùs en têi nếsōi Lakedaimoníous T.:ACC PRT beside ART others:ACC ART in ART island:DAT Spartans:ACC

katadêsai

bind:AOR.INF

'[the Athenians decided] to put Tantalos in bonds next to the other Spartans who were on the island.' (rather than 'Tantalos [they decided] to put in bonds [and bring to] other Spartans who were on the island")

(Thuc. 4.57.4)

Similarly, the use of hupò 'under' with an accusative (as opposed to a dative) noun phrase is not restricted to contexts of motion: the same combination of preposition and case is used to describe "Position or Extension under an object, without sense of motion" (LSJ, s.v. C.2), especially with objects of wide extent or coverage, such as the sun, earth, shade, or a constellation. Such combinations cannot be used as a reliable indicator of the dynamic, as opposed to static, encoding of a particular argument. Example (17) is one such allegedly "dynamic" prepositional phrase, interpreted by Kühner and Gerth (1898: 543) as involving a motion component: "to set under the light and observe" ("unter das Licht stellen und betrachten").

$\begin{array}{llll}\text { (17) taûta hup' augàs mâllon ídōmen } \\ \text { these:ACC } & \text { under } & \text { rays:ACC } & \text { rather see:AOR.SUBJ.1PL }\end{array}$

'Let us rather see these things under the rays of light.'

(Pl. Phaedr. 268)

The corresponding "static" combination of hupò with the dative of augê 'light, ray', however, is not attested in the Archaic or Classical periods, whereas the "dynamic" prepositional phrase is widely used in the expression '[look at smth] under the light [of the sun]' (Eur. Hec. 1154, Aristoph. Thesm. 500, Pl. Phaedr. 269 a). ${ }^{7}$ In light of this, the use in (17) should be interpreted as strictly locative. ${ }^{8}$

\footnotetext{
7) The idiomatic use may be related to the formula hup' augàs eeelioio 'under the rays of the sun', restricted to the end of the line and used four times in the Odyssey, with a locative meaning (2.181, $11.498,11.619,15.349)$.

8) There is similarly no evidence confirming that the phrase hupò tinà eînai 'to be under someone', in the meaning 'to be in someone's power', is a relic of an old pregnant usage, as suggested by Kühner and Gerth ("esse in potestatem, i.e. venisse in potestatem in eaque esse"). It can rather be viewed as related to the locative uses of hupo + accusative. The same use is represented in Xen. Cyneg. 3.3 (described in Kühner and Gerth [1898: 544] as constructio praegnans), where dogs avoid the sun by staying in the shade (hupò tàs skiàs).
} 
In sum, a close inspection of the alleged examples leaves us no real evidence for a special construction that would license a free, non-lexicalized use of a non-motion verb with a directional prepositional phrase. The apparently unexpected combinations of verbs not implying motion with directional expressions can be accounted for without reference to such a construction. They are instead explained in one of two ways.

First, the Ancient Greek verb may take a directional argument where its English or German counterpart does not. That argument is often associated with a highly specific semantic role that cannot be easily inferred on the constructio praegnans account (cf. the sacrificial meaning 'slaughter (into a receptacle)'). In most cases, the verb can only combine with a directional expression on a special meaning that differs from the meaning attested in the absence of a directional argument.

Secondly, the directional expression in question, rather than being restricted to dynamic contexts, may describe static locations, either with specific types of reference object or in certain idiomatic uses.

In both cases, there is nothing special about the grammar of Ancient Greek that would license the use of verbs not referring to motion with directional arguments. On the one hand, certain directional expressions are regularly used in many Indo-European languages to "project" a static spatial relation, as in the English example The table is standing to the left of the door (Nikitina forthc.). On the other hand, individual verbs that do not encode motion can lexicalize a directional argument on a verb-by-verb basis. This situation is common in the modern languages; for example, the expressions in (18) are relatively consistent in taking a directional argument to describe the location of the intended addressee:

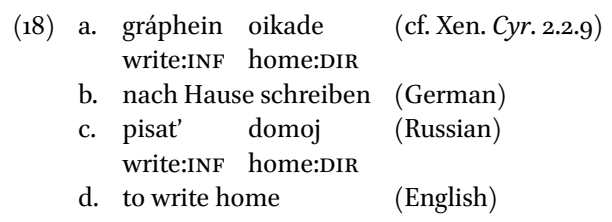

The fact that such uses are licensed by individual verbs, and do not seem to produce any discernible effect of a special "pregnant", or "elliptical", construction, undermines the constructional treatment of the Ancient Greek cases. It suggests that the notion of a Greek-specific constructio praegnans should be instead restricted to examples of a different kind: the cases where an endpoint of motion is encoded by a static prepositional phrase. In the next sections, we address such cases and show that (i) that type of use is also not unitary but subsumes three subtypes; and (ii) two of the subtypes are attested in modern Indo-European languages. 


\subsection{The Aspectual Type: Static Encoding with Perfect Participles}

The first type of context where static prepositional phrases encode endpoints of motion is the use of perfect participles. The following two examples are commonly cited as instances of constructio praegnans where the event of motion is followed by continuous rest (Kühner and Gerth 1898: 541; Moore 1934: 59; Schwyzer 1950: 434; Smyth 1956: 368):

(19) hoi en têi nếsōi ándres diabebēkótes

ART in ART island:DAT men:NOM cross.over:PTCP.PERF.NOM.PL

'the men on the island who have crossed over'

(Thuc. 7.71.7)

(20) taîs de loipaîs en têi gêi katapepheuguíais

ART PRT remaining:DAT.PL in ART ground:DAT take.refuge:PTCP.PERF.DAT.PL

enéballon

attack:IMPF.3PL

'They attacked the remaining [ships] when they have taken refuge ashore.' (Thuc. 4.14.1)

In example (19), the prepositional phrase should in fact, based on word order, be interpreted as modifying the noun ándres 'men', rather than as an argument of the verb diabaínō 'to cross over'. We do not discard this example as irrelevant, however, because it instantiates a more general phenomenon that is also reflected in other examples of "pregnant" use that involve perfect participles, such as (20).

The major difference between (19) and (20) is the absence of a head noun in (20): instead of modifying a noun (cf. 'men' in (19)), the static prepositional phrase introduces an argument of the participle katapepheuguíais 'having fled'. The participle in turn modifies the nominalized adjective loipaîs '[those] remaining. Crucially, the goal argument of the perfect participle is encoded by a static prepositional phrase ("on the shore"). We believe that the use of the static encoding is explained by the fact that the participle does not simply specify the endpoint of fleeing, but rather characterizes the ships as being located on the shore at the time of the attack. In this sense, the resultative meaning of the perfect participle is ultimately responsible for the static encoding of the goal argument with a verb that otherwise combines with directional prepositional phrases.

In Classical prose, the same verb appears one more time with a static prepositional phrase, and again the example involves a perfect participle:

(21) hoi d' en tōi Hēraíōi katapepheugótes

ART PRT in ART Heraion:DAT take.refuge:PTCP.PERF.NOM.PL

'those who have fled and taken refuge in the Heraion'

(Xen. Hell. 4.5.5) 
The perfect participle in (21) is substantivized. Due to the participle's resultative meaning, the prepositional phrase specifies both the endpoint of motion and the resulting location: at the relevant point in time, those who fled are at the Heraion.

The same explanation applies to another example that is unique in featuring a static prepositional phrase with the verb (em)piptō 'fall (in)' (with or without the prefix) in the Classical prose subcorpus (see Section 2.4 for further discussion).

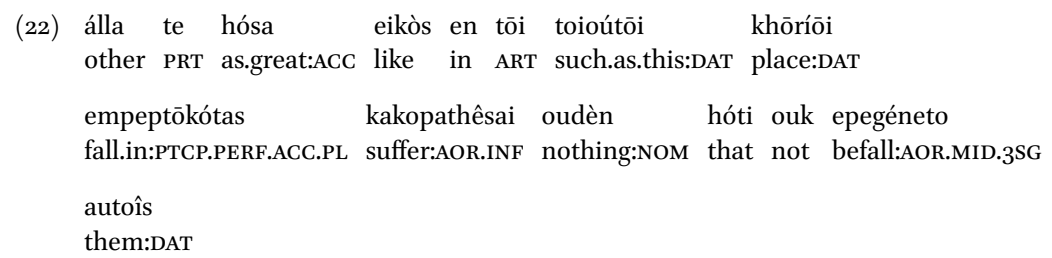

'Of all the other things that, having been thrust [lit. "having fallen"] into such a place, one is bound to suffer, there was nothing that did not befall them.' (referring to a hole in the quarries where prisoners were kept)

(Thuc. 7.87.2)

Here, the participle describes the resulting state of a preceding event: those suffering are located in the place where they have been thrust. We believe that the semantics of the perfect participle is again responsible for the static encoding of the endpoint of motion with a verb that is otherwise not attested with static encoding in Classical prose: the participant's location at the relevant point in time coincides with the endpoint of preceding motion.

Static encoding with perfect participles appears first in Thucydides (more in Section 4.1). In Xenophon, it is attested in a rare periphrastic pluperfect middle construction involving a middle perfect participle of anakomizdō 'to convey' and a finite (imperfect) form of eimi 'to be'.

(23) ó́ikoun dè en toîs okhuroîs kaì tà epitếdeia en

dwell:IMPF.3PL PRT in ART fortification:DAT.PL and ART supplies:ACC in

toútois anakekomisménoi êsan

these:DAT convey:PTCP.MP.NOM.PL be:IMPF.3PL

'They inhabited the fortifications and had all the supplies brought into them.'

(Xen. Anab. 4.7.17)

As in the previous examples with perfect participles, the static encoding is associated with the resultative meaning: at the time when the Greek army is passing by, the supplies have already been placed inside the fortifications and hence unavailable.

In the 4th century BCE, the static encoding of endpoints of motion is extended to perfect and pluperfect forms other than the participle. Plato uses 
static prepositional phrases to describe the location of result states with the perfect forms of katapheúgō 'flee' and empíptō 'fall in' (a perfect infinitive in Soph. 26od, a pluperfect in Euthyd. 293a).

In sum, the special properties of perfect participles in Classical prose motivate our treatment of such examples as instances of a distinct-aspectualtype of pregnant use. We believe that this type develops due to the participles' resultative meaning: the participles describe a participant's state at a specific point in time (cf. Chantraine 1927; Gerö \& von Stechow 2003; Haug 2008), hence the endpoint of preceding motion coincides with the participant's current location (cf. (19)). While the first unambiguous instances of the aspectual type are attested in Thucydides, later authors extend the same pattern to other perfect and pluperfect forms. While we cannot address this development in any detail, it is worth pointing out that similar correlations between static encoding and past/perfect/resultative forms are attested in other languages; see, for example, the discussion of the past participle in German (Willems 2011: 354 and references therein).

\subsection{The Change of State Type: Directional Encoding of Result States}

Static prepositional phrases can encode endpoints of motion with verbs of change of configuration, which differ from motion verbs in not implying motion, but rather specifying a position assumed by an entity (vertical, horizontal, etc.). These are verbs like títhèmi 'place', hístēmi 'install, set', kathizdō 'make sit', hidrúö/hidrúesthai 'establish, found', or the rare verb katoikizdō 'settle, establish' (e.g., Thuc. 5.35.8) (Kühner and Gerth 1898: 540-541; Ruijgh 1994: 136). With such verbs, the static encoding is an alternative to directional expressions, which are also widely attested: ${ }^{9}$

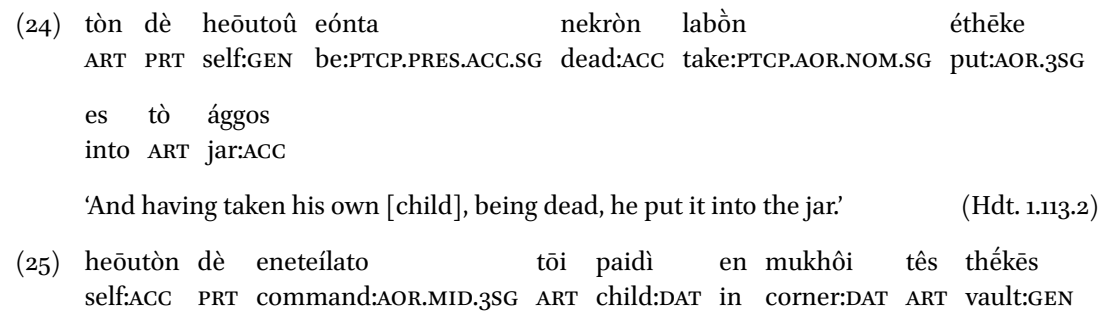

\footnotetext{
9) The variable encoding cannot be accounted for in terms of semantic types of location described as the endpoint of motion, cf. the encoding of 'put into hands' as en khersin éthēke in Hom. Il. 6.482, 21.82, Od. 8.482, 18.152, but as eis khéra thêke in Hom. Hymn to Pan 40.
} 
hōs málista theînai

as most put:AOR.INF

'He commanded his son that he lay him into the corner of the vault [as far] as possible.'

(Hdt. 3.16.7)

Change of configuration verbs are special in the way their meaning is conventionally associated with a change of location, even though a change of location is not necessarily implied. The events of assuming a sitting or lying position, for example, need not in principle be preceded by changes of location, but in reality they commonly are. Similarly, the events of taking a stand-for example, in the military context-are commonly preceded by the person moving to the position that he prepares to protect:
(26) éstan d' en leimôni Skamandríōi anthemóenti make.stand:AOR.3PL PRT in meadow:DAT of-Skamandros:DAT flowery:DAT
muríoi
countless:NOM.PL

'They in great numbers took stand in the blossoming meadow of Skamandros.'

(Hom. Il. 2.467)

The conventional association between the meaning entailed by the verb (a change of configuration), on the one hand, and the inferred preceding motion, on the other, is responsible for the apparent synonymy of static and directional prepositional phrases: the location where the change of configuration takes place coincides with the endpoint of motion that is inferred to have preceded the change of configuration.

Crucially, the directional argument of change of configuration verbs differs in two important ways from spatial goals that occur with regular verbs of motion. First, they are not restricted to describing spatial endpoints, but may instead specify the resulting configuration:

(27) a. aûthís m' es orthòn stêson

back me:ACC into straight:ACC set:AOR.IMPER.2SG

'Set me upright once again.' (cf. parallels in Soph. Oed. Tyr. 5o, Eur. frag. 262.2 Nauck)

(Eur. Orest. 231)

$\begin{array}{llll}\text { b. paraibátas } & \text { éstēsan } & \text { es táksin dorós } \\ \text { those.standing.beside:ACC } & \text { make.stand:AOR.3PL into line:ACC } & \text { spear:GEN }\end{array}$

'they brought the warriors at their sides up into line'

("into the order of the spear" = so that the warriors form a line $)^{10}$

(Eur. Supp. 677)

10) Cf. the roughly synonymous expression in (i), where the prepositional phrase also describes the resulting state or the resulting configuration of the warriors (standing in one line and ready for battle): 
Second, while verbs of motion freely combine with descriptions of the endpoint, source, or path of motion, verbs of change of configuration normally impose restrictions on the encoding of the motion's source or path. Thus, spatial sources or paths of motion are not attested with change of configuration verbs in our data. The corresponding meanings are encoded by combinations of two verbs: a change of configuration verb and a separate verb taking a source argument. In (28), for example, the source of motion does not combine directly with a change of configuration verb but must be instead introduced by a different verb-hairéó 'take'.

(28) tôi d' ára kêruks moîran helòn etíthei

he:DAT PRT then herald:NOM portion:ACC seize:PTCP.AOR.NOM.SG put:IMPF.3SG

kanéou 't' ek sîton eíras

basket:GEN PRT from bread:ACC lift:PTCP.AOR.NOM.SG

'And then a herald, having taken a portion [of meat], placed it for him, and having lifted bread from a basket [he placed it too].'

(Hom. Od. 17.335)

Differences between directional phrases attested with change of configuration verbs and goal arguments of regular motion verbs are discussed in more detail in Nikitina (2010). They are explained by a difference between goal arguments and results. Goal arguments are selected by motion verbs. They are in general compatible with descriptions of source or path. Results are selected by change of state verbs, and encoded, like goal arguments, by directional prepositional phrases. Unlike goal arguments, results do not always have the meaning of spatial endpoint, but may specify other aspects of the resulting state, such as a specific configuration (27a-b). They are normally incompatible with descriptions of spatial sources or paths, which must be introduced by other verbs, as in (28).

These differences suggest that in Ancient Greek, change of configuration verbs do not take goal arguments but instead allow for result phrases. A result phrase may specify, among other things, the object's resulting location, i.e.

$\begin{array}{llll}\text { (i) es } & \text { dóru } & \text { stathéntes } \\ & \text { into } & \text { spear:ACC } & \text { make.stand:PTCP.AOR.PASS.NOM.PL }\end{array}$

'being placed in the military order' (lit., "into the spear")

(Eur. Troiad. 934)

By contrast, a static prepositional phrase is used in (ii) with a spatial endpoint reading (the arms are supposed to be placed on a previously existing battle line, not to form a line):

(ii) thésthe tà hópla en táksei hōs tákhista put:IMPER.AOR.MID.2SG ART arms:ACC in order:DAT as most.swift

'put down the arms on the battle-line as soon as possible'

(Xen. Anab. 7.1.22) 
the endpoint of the inferred motion. In this sense, the variation in the use of static vs. dynamic prepositional phrases with change of configuration verbs is explained by a variation in the way the resulting location can be described: (i) as a location where the change of configuration takes place, or (ii) as a result of the change of configuration.

Change of configuration verbs are just one-the most coherent and easily defined-semantic class of verbs that allow for result phrases specifying location. Some other change of state verbs behave in exactly the same way, suggesting that directional phrases encoding resulting locations are allowed with various kinds of change of state, provided that the change is routinely associated with a change of location.

The verbs katakleío 'to enclose, shut in' and katheírgnumi/kateírgō 'to shut in, confine' are used to describe changes from a free to an imprisoned state (construed in broad terms as a state of restricted mobility). ${ }^{11}$ Unlike verbs of motion, they are commonly attested without an overt description of the place of imprisonment (29a). Alternatively, the place where the change of state takes place is described by a static locative modifier $(29 b)$.

(29) a. katéklēisan dè toû autoû kheimônos kaì Makedónas shut.in:AOR.3PL PRT ART self:GEN winter:GEN and Macedonians:ACC

Athēnaîoi

Athenians:NOM

'The same winter the Athenians also blockaded Macedonia.'

(Thuc. 5.83.4)

b. Epeidè gàr Lakedaimoníōn elthóntōn ho demos en tôi

after PRT Spartans:GEN come:PTCP.AOR.GEN.PL ART people:NOM in ART

Peiraieî katekleísthē

Piraeus:DAT shut.in:AOR.PASS.3SG

'when the Spartans came, the people were confined in the Piraeus.'

(Isocr. 18.49)

The change is commonly associated with preceding motion (since prisoners are often kept in specially designated places). Hence the verb can co-occur with a directional phrase specifying the result of change; in the case of a spatial prepositional phrase, it is the resulting location. The spatial result is roughly synonymous with static locative modifiers ((29b) vs. (30); also Xen. Hell. 3.2.3, Dem. 3.31, Dem. 18.97 for parallel uses of katheírgnumi/kateírgō 'to shut in, confine').

11) The verb katakleío 'to enclose, shut in' is not attested before Thucydides. The verb katheírgnumi / kateírgō 'shut in, confine' is first attested (without a locative or a directional phrase; cf. (29a)) in Archaic poetry (Hom. Hymn to Hermes, 356). 
(30) ekboēthếsantas dè toùs Andríous etrépsanto kaì come.to.aid:PTCP.AOR.ACC.PL PRT ART Andrians:ACC turn:AOR.MID.3PL and

katékleisan eis tè̀n pólin

shut.in:AOR.3PL into ART city:ACC

'[The Athenians] put to flight the men of Andros, who came forth to aid, and shut them up in their city'

(Xen. Hell. 1.4.22)

Crucially, when the event of imprisonment is not associated with motion, only static locative modifiers are attested with both verbs, as in (29b) or (31). This suggests that the directional encoding is not a verb-specific way of realizing that particular argument, but an additional option that is only available in cases where motion is inferred to precede the change of state.

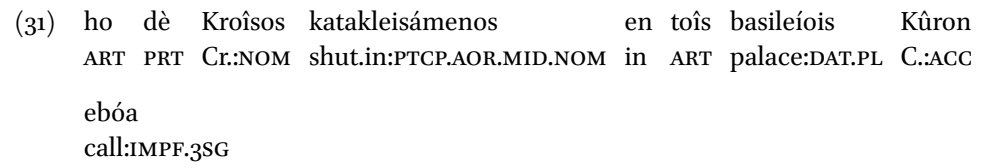

'But Croesus, having shut himself up in his palace, was calling for Cyrus.' $\quad$ (Xen. Cyr. 7.2.5)

A similar behavior characterizes some other change of state verbs, such as kataskēnóo 'to take up one's quarters, encamp' and athroízdō (Att. hathroízdō) 'to gather, collect, amass' (and its prefixed counterpart sunhathroizdō 'to assemble $^{\prime 2}$ ). The verbs refer, stricto sensu, to changes to a camping state (usually from a state of being on the march, cf. Xen. Anab. 3.4.33) and to a state of concentration/compact configuration (from a state of dispersal), respectively (note that the latter verb differs in its behavior from other verbs of collecting, which describe motion to a single location from several different places, see Section 2.1). The location where the change of state takes place can be described by a static locative modifier ((32a), cf. Thuc. 1.50.4), and this is the only option available in descriptions of changes of configuration, from a dispersed to a congregated state, without a change of location from outside to inside the reference object $(32 b)$. On the other hand, the verbs can combine with a directional phrase specifying the resulting location; in this case, the accompanying change of location is inferred (32c).
$(32)$
32) a. hòs
$\begin{array}{lll}\text { when } & \text { PRT } & \text { multitude:NOM }\end{array}$
en stenôi
neôn
éthroist'

'when the multitude [of ships] had been gathered in the narrows'

(Aesch. Pers. 414)

\footnotetext{
12) Poppo's (1889: 225) discussion of sunhathroízdō 'to assemble' in Thuc. 2.99.1 does not take into account the possibility that the use describes a change of state at a certain location, and need not involve preceding motion (cf. an unambiguous example in Thuc. 7.86.1).
} 
b. Ouranòs athroízdōn ástr' en aithéros kúklōi

Ouranos:NOM gather:PTCP.PRES.NOM.SG stars:ACC in Aether:GEN circle:DAT

'Ouranos gathering stars in the Aether's circle' (description of a visual representation) ${ }^{13}$

(Eur. Ion 1147)

c. hoi dè Surakósioi hathroisthéntes es tè̀n Helōrínēn

ART PRT Syracusans:NOM gather:PTCP.AOR.PASS.NOM.PL into ART Helorine:ACC

hodòn ...

road:ACC

'The Syracusans, having gathered on the Helorine road ...'

(Thuc. 6.70.4)

More generally, certain changes of state, which are commonly associated with preceding changes of location, are lexicalized in Ancient Greek by verbs that combine with spatial results. Similar use of directional phrases is attested with precisely the same semantic class of verbs in other languages. For example, the directional encoding of resulting locations with change of state verbs produces a similar variation between static and directional encoding in Russian (Nikitina 2010). Strikingly, the specific changes of state that are lexicalized by such verbs in the two languages are largely the same,$^{14}$ suggesting that the phenomenon depends on the association of certain changes of state with relocation.

With change-of-state verbs, the use of directional phrases is further constrained by additional factors. The most obvious factor is the perfect aspect, which tends to be associated with the stative resultative meaning (cf. the discussion in Section 2.2). As the perfect is used to describe a state following a change of configuration, rather than the event of such change, it tends to cooccur with static encoding. ${ }^{15}$ Static prepositional phrases describe the location where the resulting state holds, understood as the endpoint of preceding

13) The event does not seem to involve a relocation from outside to the inside of the reference object: it seems unlikely that the stars originate outside the "Aether's circle", which is commonly taken to subsume the entire universe above the terrestrial sphere. Most likely, the stars are being grouped together within the "circle".

14) Cf., e.g., the following Russian examples:

(iii) Oni seli na skamejke/ na skamejku they sat.down on bench:PREP on bench:ACC

'They sat down on a bench.'

(iv) Oni zaperli den'gi $\mathrm{v}$ sunduke / $\mathrm{v}$ sunduk they shut.in money in chest:PREP in chest:ACC

'They shut the money in a chest.'

15) We tried to avoid using examples with perfect verb forms in this section, to emphasize the fact that static encoding is not restricted with verbs of this class to contexts with the perfect, in spite of being particularly well-represented in such contexts, cf. footnote 18 . 
motion. For example, in our corpus, perfect (and pluperfect) forms of hístēmi 'install, set' only occur with static en + dative phrases (39 occurrences).

\subsection{The Genuine "Pregnant" Use: The Static vs. Directional Alternation}

Our last type of constructio praegnans subsumes instances of static encoding of unambiguous spatial endpoints with regular verbs of motion. This variation is attested with verbs of externally caused motion, such as bállō 'to throw, cast', píptō 'to fall', (kath)híemi 'to throw', elaúnō 'to drive (smth. into smth.)', and it is especially characteristic of early stages of Ancient Greek (cf. also example 1).

(33) Héktori dè propároithe podôn pésen en koníēisi Hector:DAT PRT before feet:GEN fall:AOR.3SG in dust:DAT.PL

'He fell in the dust beside Hector's feet.'

(Hom. Il. 13.205)

(34) kaì tês oreías anthemórruton gános ksouthês melíssēs and ART mountainous:GEN flowing.from.flowers:ACC pride:ACC yellow:GEN bee:GEN

es puràn balô séthen

into fire:ACC throw:FUT.1SG you:GEN

'I will throw onto your funeral pyre the honey of tawny mountain bees that streams from flowers.'

(Eur. Iph.T. 634-635)

As in the case of the previous type of constructio praegnans, the variation cannot be explained away by differences in the type of endpoint (an otherwise important factor in the choice of prepositional encoding, cf. Luraghi 2003), as the same types of noun phrase are attested with static and with directional encoding without any obvious difference in meaning. Thus, en puri 'in fire' appears in Hom. Il. 9.220, 18.474, Od. 3.446, but the directional alternative is attested in Euripides (ex. 34), and Herodotus uses es tò pûr 'into the fire' (7.107). Similarly, Homer's metaphorical use of static encoding with eni thumô bállein 'put in one's mind' (Od. 1.201, 15.173; also with the middle of bállō in Il. 14.50, 15.566, Od. 12.218) corresponds to dynamic es thumòn 'into mind' in Soph. Oed. Tyr. 975 (with the middle of bállō: Hdt. 1.84, 7.51, 8.68).

Besides verbs of externally caused motion, the static encoding of goals is attested at the earliest stage (in the Iliad) with the verbs bainō, in the meaning of 'step', and thrốiskō, in the meaning of 'leap, attack':

(35) hò dè làks en stéthesi baínōn he:NOM PRT with.foot in chest:DAT.PL step:PTCP.PRES.NOM.SG

'He stepped on [the enemy's] chest with his feet.'

(Hom. Il. 13.618, 16.503; cf. 6.65)

Characteristically, static encoding is not attested with the same verbs on the self-propelled motion reading: 'walk' and 'jump', respectively (cf. Létoublon 1985: 140-141 on baínō). 
Unlike change of configuration verbs, regular verbs of motion-such as the verbs of externally caused motion in (33)-(34) — not only take goal arguments, but can also combine with descriptions of source or path.

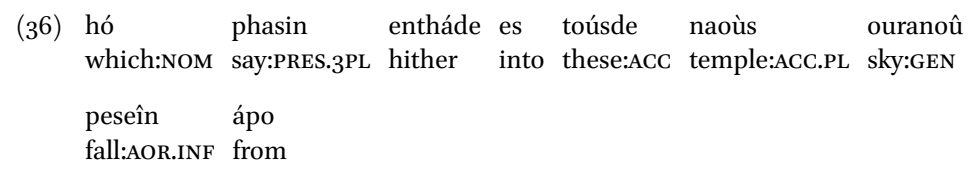

(Eur. Iph.T. 88)

Static prepositional phrases normally cannot be interpreted with such verbs as describing a location where the event took place, but receive the interpretation of the endpoint of motion. This type of variation is not restricted to any particular aspect, such as the perfect (cf. Section 2.2). ${ }^{16}$ Neither can it be described in terms of a difference in the meaning of a particular motion verb (cf. Section 2.1): the verb can be used with a directional argument or with a static prepositional phrase on exactly the same reading. In this sense, the use of static encoding in (33) - (34) is a genuine instance of a "pregnant" construction as described in traditional grammar. Consistent with the observation in Kühner and Gerth (1898: 541), it is particularly characteristic of Homeric Greek, and as such may be associated with archaic poetic style.

Even this type of variation, however, is not unique to Ancient Greek. For example, American English regularly encodes goals of motion by static prepositional phrases, and this encoding is especially common with verbs of externally caused motion (Nikitina 2008). In (37a-b), a goal of motion can be described by a static or by a directional prepositional phrase, without any obvious difference in meaning. In the presence of a motion verb, the fact that the static prepositional phrase introduces a goal of motion is easily inferred, and does not require explicit encoding.

(37) a. The ball fell in / into the water.

b. I threw the ball in / into the water.

\section{Diachronic Changes}

\subsection{The Lexical and the Aspectual Types}

The classification proposed in the previous section is supported by the way diachronic changes affected the different types of constructio praegnans in the

\footnotetext{
16) We have no evidence for the same association of the perfect forms of regular motion verbs
} with the static encoding as in the case of change of configuration verbs, discussed in Section 2.3. 
period from Archaic to Classical Greek. We review the development of the four types of construction below, starting with the lexical type.

As discussed in Section 2.1, the lexical type of constructio praegnans is attested with verbs that do not encode any motion but nevertheless can take a directional argument. We have not been able to detect any significant changes in the use of such verbs, apart from changes in individual verbs' argument structure. While specific verbs, or specific meanings, go out of use, the process does not seem to follow any consistent pattern. In view of the arbitrary character of such changes, we conclude that no uniform diachronic development affected the lexical type of constructio praegnans in the relevant period.

The aspectual usage, on our account, is triggered by the resultative meaning of perfect participles. All examples in our data come from Thucydides and Xenophon, i.e. from the latest portions of our corpus. We conclude that the aspectual type of "pregnant" use is a relatively late development; as we saw in Section 2.2, the aspectual type is extended to other perfect forms in Attic prose postdating Thucydides.

\subsection{The Change of State Type}

The change of state type of constructio praegnans is defined as the use of directional prepositional phrases with change of state verbs, which do not entail motion (but are nevertheless commonly associated with it) and do not take goal arguments. The directional encoding is attested from early on, but its proportion increases dramatically in the later portions of the corpus. To illustrate this change, we present below the distribution of two types of prepositional phrase-the static en + dative 'in $\mathrm{x}$ ' vs. the directional eis + accusative 'into $\mathrm{x}^{\prime}$ - with selected verbs of change of configuration.

The verbs were chosen based on two factors: they had to be relatively frequent, and their meaning had to remain constant throughout the relevant period in the history of Ancient Greek (see Table 1 in Section 1 for the subcorpora used in this study). In order to be included in the counts, the prepositional phrase was required to describe an endpoint of motion. Only examples describing literal motion were included; examples with non-spatial prepositional phrases and idiomatic uses were not counted. In addition, we excluded all cases (almost entirely restricted to Homer) where the preposition's argument was not adjacent to the preposition, since such examples could be alternatively analyzed as instances of an old adverbial-rather than prepositional-use of the corresponding form.

Tables 2-3 present the frequency of occurrence of the two types of prepositional phrase with the most frequent verbs of change of configuration: histèmi 'stand, set' and tithèmi 'put, place'. The tables are followed by figures that repre- 
sent changes in the relative frequency of the two expressions. The subcorpus of Attic comedy was excluded from the counts, due to the small number of occurrences of the two verbs with relevant prepositional phrases (only 3 instances of hístèmi 'stand, set', 4 instances of títhèmi 'put, place').

Table 2 presents the proportions for the verb histēmi 'stand, set'. The verb combines almost exclusively with static endpoints in the Iliad and in Archaic poetry (the only exception occurs in the Odyssey). A different trend is observed in Attic Greek, where the dynamic encoding is well attested (19\% of all instances in tragedy, and $26 \%$ in prose). ${ }^{17}$

Table 2. Endpoints of motion with hístēmi 'stand, set'

\begin{tabular}{|c|c|c|c|c|}
\hline & Homer & Archaic poetry & Attic tragedy & Classical prose \\
\hline$e n+$ dat & $(98 \%)$ & $(100 \%)$ & $(81 \%)$ & $(74 \%)$ \\
\hline eis + acc & $(2 \%)$ & $(0 \%)$ & $(19 \%)$ & $(26 \%)$ \\
\hline Total & $44 \quad(100 \%)$ & $9 \quad(100 \%)$ & $16 \quad(100 \%)$ & $57 \quad(100 \%)$ \\
\hline
\end{tabular}

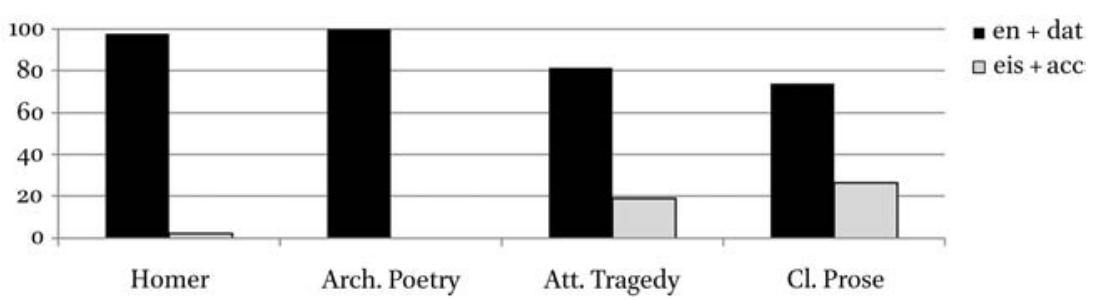

Figure 1. Gradual shift in the goal-encoding strategy with hístēmi 'stand, set'

From early on, additional factors, such as aspect, have been at play in the choice between static and directional encoding with change of configuration verbs. All perfect forms of the verb histèmi 'stand, set', for example, are used with static encoding. This pattern, however, differs in important ways from the behavior of the aspectual type of constructio praegnans as described in Section 2.2: (i) the static encoding is widely attested with change of configuration verbs outside constructions with the perfect aspect, (ii) the static encoding is attested with perfect forms from the earliest stages, and (iii) it shows no discernible effect of the use of participles vs. other forms. ${ }^{18}$

17) In spite of the small numbers, the difference between Homer, on the one hand, and Classical prose, on the other, is highly significant: $\mathrm{p}<0.001$ (Fisher's Exact Test).

18) The following numbers summarize the distribution of perfect forms of histemi (only occurring with en + dative) in the four relevant subcorpora: Homer-12 (perfect) vs. 32 (other), Archaic poetry -4 (perfect) vs. 5 (other), Attic tragedy -3 (perfect) vs. 10 (other), Classical prose -20 (perfect) vs. 22 (other). 
The same development is attested with another relatively frequent change of configuration verb-tithèmi 'put, place' (Table 3, Figure 2). Although directional prepositional phrases are present in the corpus from the earliest times (10\% in Homer, $9 \%$ in Archaic poetry), their percentage increases dramatically in the Classical period ( $42 \%$ in tragedy, $65 \%$ in prose). ${ }^{19}$ No perfect forms occurred with this verb in our corpus, which contributed to a sharper increase in directional encoding.

Table 3. Endpoints of motion with tithēmi 'put, place'

\begin{tabular}{lrrrrrrrr}
\hline & \multicolumn{2}{c}{ Homer } & \multicolumn{2}{c}{ Archaic poetry } & \multicolumn{2}{c}{ Attic tragedy } & \multicolumn{2}{c}{ Classical prose } \\
\hline en + dat & 86 & $(90 \%)$ & 20 & $(91 \%)$ & 22 & $(58 \%)$ & 18 & $(35 \%)$ \\
eis + acc & 6 & $(10 \%)$ & 2 & $(9 \%)$ & 16 & $(42 \%)$ & 33 & $(65 \%)$ \\
Total & 92 & $(100 \%)$ & 22 & $(100 \%)$ & 38 & $(100 \%)$ & 51 & $(100 \%)$ \\
\hline
\end{tabular}

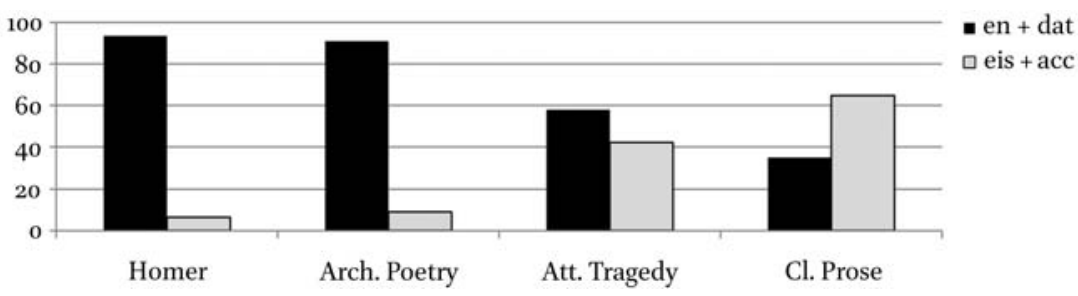

Figure 2. Gradual shift in the goal-encoding strategy with tithēmi 'put, place'

Although the distributions of the two verbs differ in detail, they follow the same major trend: the Classical period sees an increase in the use of directional prepositional phrases as compared to static ones. The same trend is observed with two minor change-of-configuration verbs, albeit these verbs are not frequent enough to provide, on their own, the basis for a solid conclusion. The data is summarized in Table 4, for three subcorpora only (the corpus of Archaic poetry does not provide enough data).

Table 4. Distributions of prepositional phrases with two minor change of configuration verbs

\begin{tabular}{llccc}
\hline verb & endpoint & Homer & Attic tragedy & Classical prose \\
\hline (kath)hízdō 'seat, sit down' & en + dat & 9 & 7 & 7 \\
& eis + acc & 2 & 6 & 22 \\
(kath)hézomai 'sit down' & en + dat & 13 & 2 & 2 \\
& eis + acc & 4 & 1 & 5 \\
\hline
\end{tabular}

19) The difference between Homer and Attic tragedy is highly significant: $p<0.001$ (Fisher's Exact Test); the difference between Attic tragedy and Classical prose is marginally significant: $\mathrm{p}<0.03$ (Fisher's Exact Test, 2-Tailed). 
Although the numbers are too small for a comprehensive statistical analysis, the data is consistent with the pattern observed for the two major change of configuration verbs: both (kath)hízdō 'seat, sit down' and (kath)hézomai 'sit down' are predominantly used with static prepositional phrases in Homer, but show a reverse preference in Classical Greek prose. Figure 4 represents the gradual shift in the use of the two change-of-configuration verbs from Table 4, taken together. ${ }^{20}$

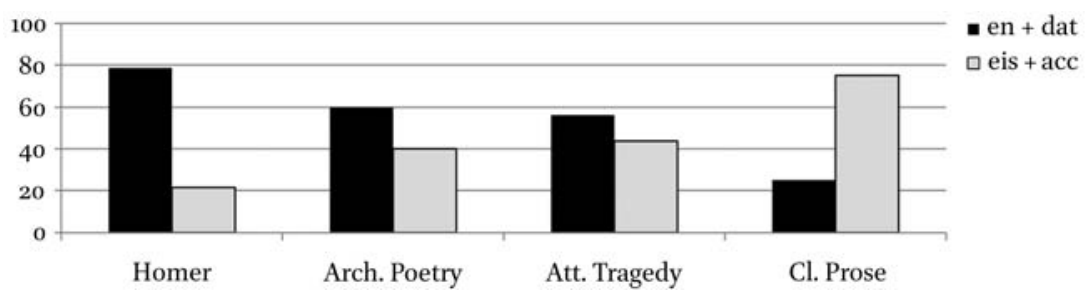

Figure 3. Gradual shift in the goal-encoding strategy with (kath)hízdō 'seat, sit down' and (kath)hézomai 'sit down'

The pattern confirms the general observation that in the period from the 8th to the 4 th $\mathrm{c}$. BCE, verbs of change of configuration gradually increased the proportion of directional (result) encoding. At the same time, static prepositional phrases continue being used with such verbs on a regular basis to encode a location where the change of configuration took place, leaving the change of location to be inferred from context.

\subsection{The Genuine "Pregnant" Use}

We now turn to changes affecting the last type of constructio praegnans, which we described above as the use of static prepositional phrases to encode goal arguments of motion verbs. The most frequent verbs allowing for the static encoding of endpoints are verbs of externally caused motion. They describe involuntary motion (píptō 'fall') or motion caused by an external agent (bállō 'throw, cast', (kath)hiemi 'cast'). Verbs describing self-propelled motion are not attested with static prepositional phrases. ${ }^{21}$

20) The difference between Homer and Classical prose is highly significant: $p<0.001$ (Fisher's Exact Test).

21) The alleged examples of such verbs with static en + dative combinations are explained by other factors, such as the use of the perfect participle (see Section 2.2). 
Table 5 and Figure 4 show the distribution of the two types with the verb of externally caused motion piptō 'fall'. As in the previous section, the counts for motion verbs only include examples involving a spatial endpoint. ${ }^{22}$ The counts also include examples where the same verb appears with the prefixes em- 'in' (i.e., en-) or eis/es- 'into' (since Classical Greek has a strong preference for the use of prefixed, rather than plain motion verbs ${ }^{23}$ ).

Table 5. Endpoints of motion with píptō 'fall'

\begin{tabular}{lrrrrrrrr}
\hline & \multicolumn{2}{c}{ Homer } & \multicolumn{2}{c}{ Archaic poetry } & \multicolumn{2}{c}{ Attic tragedy } & \multicolumn{2}{c}{ Classical prose } \\
\hline en + dat & 28 & $(100 \%)$ & 9 & $(60 \%)$ & 8 & $(31 \%)$ & 0 & $(0 \%)$ \\
eis + acc & $\mathrm{o}$ & $(\mathrm{o} \%)$ & 6 & $(40 \%)$ & 18 & $(69 \%)$ & 19 & $(100 \%)$ \\
Total & 28 & $(100 \%)$ & 15 & $(100 \%)$ & 26 & $(100 \%)$ & 19 & $(100 \%)$ \\
\hline
\end{tabular}

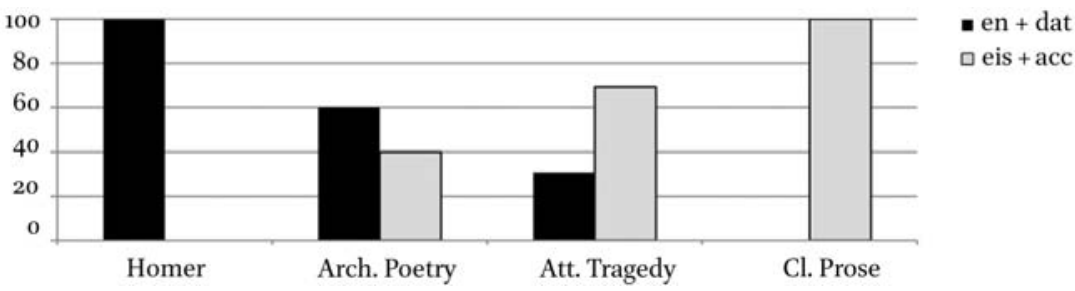

Figure 4. Gradual shift in the goal-encoding strategy with píptō 'fall'

The figure is similar in some respects to the ones presented in the previous section, but different in others. In Table 5 , as with change of configuration verbs, directional prepositional phrases gradually gain in frequency. In the case of

22) For example, the uses of the verbs piptō 'fall' in the meaning of 'perish', as in Xen. Hell. 3.4.24, were excluded. This passage is often wrongly adduced as an example of constructio praegnans (Smyth 1956: 368; Skopeteas 2008a: 40, 2008b: 6o). In fact, Xenophon reserves unprefixed forms, when used of human beings, for a specialized meaning 'to fall in battle' (Hell. 4.4.12, Hell. 4.2.20). The context confirms the non-motion interpretation 'while some were killed on the spot in the river, others tried to escape', cf. the next sentence: 'The Greeks pursued the Persians and captured their camp', implying that some of those trying to escape were killed in pursuit-in contrast to those who were slain euthùs 'on the spot, immediately'.

23) Classical authors show dialectal and individual variation in the use of prefixes: Herodotus and Thucydides prefer forms with es- (they do not use forms with eis-) over forms with em-, while Xenophon strongly prefers forms with $\mathrm{em}$ - to forms with eis- (and does not use es-forms). By contrast, no preference for prefixed forms is observed with change of configuration verbs (presumably due to the absence of a lexicalized motion component in their meaning). The fact that change of configuration verbs less frequently appear with the same prefixes as motion verbs, but instead regularly combine with the prefix kata-, suggests once again that the two types of verb belong to two different semantic classes. 
pipto 'fall', however, the change is remarkably abrupt: the directional encoding is unattested in Homer, but comes to be used as the only available option in Classical prose. $^{24}$

A similar pattern is attested with the verb bállō 'throw, cast', which is also used exclusively with dynamic encoding in Classical prose. For this verb, we include data from an additional subcorpus-Attic comedy. In light of the relative proximity of the language of comedy to contemporary spoken idiom (as compared to the language of tragedy), one may infer that directional encoding was most likely the only available option in colloquial Attic Greek in the classical period. ${ }^{25}$

Table 6. Endpoints of motion with bállō 'throw, cast'

\begin{tabular}{|c|c|c|c|c|c|}
\hline & Homer & Archaic poetry & Attic tragedy & Attic comedy & Classical prose \\
\hline$e n+$ dat & $35 \quad(81 \%)$ & $6 \quad(55 \%)$ & $5 \quad(25 \%)$ & o $\quad(0 \%)$ & o $\quad(0 \%)$ \\
\hline$e i s+a c c$ & $(19 \%)$ & $5 \quad(45 \%)$ & $15 \quad(75 \%)$ & $15(100 \%)$ & $24(100 \%)$ \\
\hline Total & $43(100 \%)$ & $11 \quad(100 \%)$ & $20 \quad(100 \%)$ & $15(100 \%)$ & $24(100 \%)$ \\
\hline
\end{tabular}

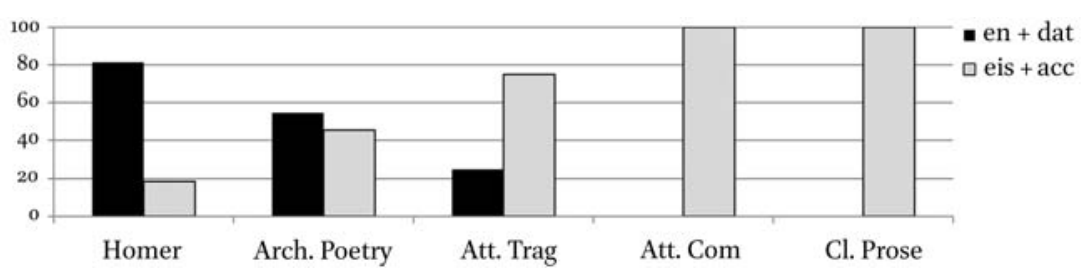

Figure 5. Gradual shift in the goal-encoding strategy with bállō 'throw, cast'

As with píptō 'fall', the verb bállō 'throw, cast' no longer occurs with static prepositional phrases in the Classical period. The change may have in fact affected the colloquial language long before it was reflected in the literary tradition; in particular, the archaizing style of Attic tragedy is likely to have preserved the more conservative norm after it was no longer current in the colloquial language. ${ }^{26}$

24) Homer differs significantly from Archaic poetry and all other subcorpora $(p<0.01$, Fisher's Exact Test); Classical prose differs significantly from Archaic poetry $(\mathrm{p}<0.01)$ and from Attic tragedy $(\mathrm{p}<0.2)$. An apparent counterexample to the exclusive use of directional encoding in the Classical period (Thuc. 7.87.2) was discussed in Section 2.2 as an instance of the aspectual type of "pregnant" use.

25) Although we do not report data from Attic comedy for píptō 'fall', due to small numbers, it is worth mentioning that all 5 uses in Aristophanes feature a directional prepositional phrase, i.e. static encoding is also not attested.

26) The same pattern is attested with the verb (kath)hiemi 'throw (down)': Homer-12 static 
Most importantly, the distributions show that the option of using a static prepositional phrase for the encoding of spatial endpoints has become obsolete in the later period reflected in our corpus. In this sense, the real "pregnant" construction seems to have gone out of use by the $5^{\text {th }} \mathrm{c}$. BCE. From early on, the construction is restricted to verbs of externally caused motion, suggesting that the change affected verbs of self-propelled motion first (cf. the use of baino 'step' and thrốiskō 'leap, attack' with static prepositional phrases in the Iliad, but not as self-propelled motion verbs). The pattern is consistent with our analysis of the different kinds of constructio praegnans, as it shows a difference in the way a common diachronic change - the general increase in the proportion of directional marking - affects the two different verb classes we have identified (change of state vs. motion). We discuss implications of this difference in the last section.

\section{Conclusions}

\subsection{Four Types of constructio praegnans}

Contrary to the widely held view of constructio praegnans as a unitary phenomenon characteristic of Ancient Greek, it is possible to distinguish between four distinct and largely unrelated phenomena, all of which produce the impression of a static prepositional phrase appearing "in place of" a directional one, or vice versa.

The first phenomenon has to do with cross-linguistic differences in the argument structure of certain verbs - verbs that do not describe a change of location proper, but are commonly associated with such a change in some conventional and verb-specific way. Writing often results in a letter travelling to an intended location; escaping from a danger is usually associated with relocation; ritual sacrifice may be accompanied by collecting blood into a receptacle, etc. A verb that describes an event of this kind may come to incorporate into its argument structure the endpoint of associated motion. This phenomenon is widely attested in other languages, and may even be universal. Verbs of this type typically assign to their directional argument a very specific semantic role; the roles depend on the type of event described and vary from one verb to another. More generally, the lexical type of constructio praegnans is special in not allowing for any variation in the encoding of the directional argument. The mistaken impression of an unexpected directional expression is produced by a difference

vs. 3 directional PPs; Archaic poetry—2 static vs. o directional PPs; Attic tragedy—1 static vs. 15 directional PPs; Classical prose — o static vs. 6 directional PPs. Due to low overall frequency, the differences are not statistically significant. 
between the argument structure of the Ancient Greek verb and its translational equivalent in a modern language.

The second phenomenon has to do with the aspectual meaning of perfect participles. Such participles describe resulting states, and may characterize participants as located, at the relevant moment, at the endpoint of preceding motion.

The third phenomenon is restricted to verbs of change of state and has to do with the fact that directional prepositional phrases can encode, in Ancient Greek, not only endpoints of motion, but also results of changes of state. In combination with a change of state verb, result phrases may be interpreted in spatial terms, as describing the spatial location of the object. That location happens to coincide with the endpoint of preceding motion.

The last phenomenon is the genuine variation in the encoding of spatial goals with unambiguous motion verbs. This variation turns out to be restricted to only a few verbs, primarily verbs of externally caused motion, and is limited to the earliest period of the history of Ancient Greek.

Table 7 summarizes the development of the four types of construction over time. The lexical type of constructio praegnans does not undergo any systematic change. This is expected given that the lexical type reflects cross-linguistic variation in the argument structure of individual verbs, and does not depend on the use of any special construction. The aspectual type is not attested until the Classical period. The change of state type is attested at the earliest stage (in the form of occasional use of directional encoding), and persists throughout the history of Ancient Greek. Finally, the genuine "pregnant" use is only observed with selected verbs at the earliest stages, and disappears in the Classical period.

Table 7. Diachronic changes in the four types of constructio praegnans

\begin{tabular}{lll}
\hline Type & Summary & Development \\
\hline lexical & $\begin{array}{l}\text { directional encoding of arguments } \\
\text { with verbs that do not imply motion }\end{array}$ & changes affect individual verbs \\
aspectual & $\begin{array}{l}\text { static expressions with perfect } \\
\text { participles (and later, other perfect } \\
\text { forms) of motion verbs }\end{array}$ & Classical prose only \\
change of state & $\begin{array}{l}\text { directional expressions with change } \\
\text { of state verbs }\end{array}$ & $\begin{array}{l}\text { attested from early on; gradually } \\
\text { gains in frequency }\end{array}$ \\
the genuine & $\begin{array}{l}\text { static encoding of goal arguments } \\
\text { with verbs of motion }\end{array}$ & disappears by the Classical period \\
\hline pregnant" use & with & \\
\hline
\end{tabular}




\subsection{Gradual Expansion of the Directional Encoding}

The gradual decrease in the static encoding of spatial endpoints is directly related to the general expansion of directional marking in the post-Archaic period. The expansion amounted to a shift toward more consistent encoding of directed motion by means of prepositions, i.e. to a more consistent use of the "satellite-framed" strategy (as opposed to the "verb-framed" strategy, which relies on the encoding of directed motion as part of the verb's meaning, cf. Talmy 1985: 57, Talmy 2000: 27; Slobin 1996: 214, among many others). This development reflects, more generally, a gradual reorganization of the prepositional system that started with the introduction of directional preposition + case combinations and was still underway in pre-Classical Greek.

At the origin of Ancient Greek preposition + case combinations were combinations of particles and free-standing noun phrases. Preposition + accusative combinations derived from the use of directional particles with "telic accusatives" (Meillet and Vendryes 1953: 552-553; overview in Meier-Brügger 2003: 266-268). A construction reaching back to Proto-Indo-European, "telic", or "goal" accusatives, were used to delimit the extent of motion, or mark its endpoint (García-Ramón 1995). The encoding of spatial endpoints was but one of the multiple inherited functions of the Greek accusative (Delbrück 1879: 29-37); presumably, accusatives could only be used in this function with a restricted set of motion verbs. In combination with directional particles, such accusatives were eventually reanalyzed as arguments of prepositions (Chantraine 1963: 84; Horrocks 1981; Hewson and Bubenik 2006). As the newly introduced preposition + accusative combinations became a specialized means of encoding direction, they started expanding their use (De Mauro 1960: 224229) and gradually became the obligatory way of encoding endpoints of motion.

This process can be illustrated with the development of the specialized preposition eis/es 'into' - an innovation restricted to Attic-Ionic and Doric dialects. We hypothesize an early period in the history of Greek when the specific spatial configuration ("Containment") was encoded by a combination of the preposition en (derived from the particle en) with a dative noun phrase. The en + dative combination could describe indiscriminately static locations and endpoints of motion, as in languages lacking specialized directional prepositions (Nikitina 2009; Beavers et al. 2010, inter alia). The archaic use of this combination to encode goals of motion is still attested in Homeric Greek, in the instances of the "genuine" constructio praegnans (Section 2.4).

Alternatively, directionality could still be encoded at that stage by the particle en 'in' (homophonous with the preposition), possibly in combination with a 
telic accusative. ${ }^{27}$ The archaic use of the particle $e n$ with a directional meaning is attested in Homer in rare cases of tmesis - the non-adjacent placement of particles (which are later to develop into "preverbs") and the verb (Haug 2012: $100)$, as in (38):

(38) en dè tà mêla labóntes ebếsamen

in PRT ART sheep:ACC take:PTCP.AOR.NOM.PL make.go:AOR.1PL

'we took the sheep and put them aboard'

(Hom. Od. 11.4; cf. Il. 23.481) 28

The combinations of the particle en with a telic accusative were eventually reanalyzed as prepositional phrases with an accusative argument, restricted to the encoding of goals of motion. The new specialized directional combination started expanding to contexts where the "neutral" en + dative combinations had been used previously. Eventually, some of the dialects (Attic-Ionic and Doric) innovated the preposition eis/es (from en $+s$ ), which replaced the earlier en in directional contexts (with an accusative argument). ${ }^{29}$

In Homeric Greek, the new directional expression is still expanding its use. As suggested by changes in the proportion of directional vs. static prepositions in Table 8, the specialized directional encoding continues to be extended to new contexts throughout the history of Ancient Greek, up to the Classical period. ${ }^{30}$ As a result of this process, the originally "neutral" combinations become restricted to contexts not describing motion-the development that culminated in Attic prose, where en + dative combinations could no longer encode endpoints of motion.

\footnotetext{
27) We assume that the en + dative combination was reanalyzed as a prepositional phrase earlier than the en + accusative combination. While this assumption is not crucial to our analysis, it is indirectly confirmed by the fact that the use of goal accusatives is still relatively widespread in Homeric Greek (e.g., Od. 3.162, 8.362), while the use of free-standing datives in the locative meaning is rare and "heavily conditioned by the lexical features of NPs" (Luraghi 2003: 65).

28) Unusually, es occurs in tmesis in Il. 1.310: es d'hekatómbēn bêse theôi 'and he put on board the ship the hecatomb for the god'. This appearance of $e s$ as an apparent adverb is most likely a quirk of the late Homeric diction (the whole passage may derive from a separate prooimial composition attached to the main body of the Iliad, see Faraone forthc.).

29) The combination of $e n$ with an accusative argument is attested in the corpus of Archaic poetry (Pindar, Pyth. 2.11, Pyth. 5.38, fr. 75.1), which commonly features non-Attic-Ionic elements, as well as in Thessalian, Boeotian, and Cypriot dialects (Wackernagel 2009 [1928]: 593; Meillet and Vendryes 1953: 553; Morpurgo Davies 1964: 151). The preposition ens is attested, for example, in Cretan (Meillet and Vendryes 1953: 137).

30) Eventually, the static preposition gets replaced by what used to be the directional preposition eis; for the development of the prepositional system in post-Classical and Medieval Greek, in relation to changes in case marking, see Skopeteas (2008a), Bortone (2010).
} 
Table 8. Increase in the proportion of eis/es 'into' compared to en 'in'

\begin{tabular}{|c|c|c|c|c|c|}
\hline & Homer & Archaic poetry & Attic tragedy & Attic comedy & Classical prose \\
\hline eis 'into' & $(31 \%)$ & $(33 \%)$ & $(44 \%)$ & $(48 \%)$ & $(52 \%)$ \\
\hline en 'in' & $(69 \%)$ & $(67 \%)$ & $(56 \%)$ & $\left(5^{2} \%\right)$ & $(48 \%)$ \\
\hline Total & $3175(100 \%)$ & $1737(100 \%)$ & $5353(100 \%)$ & $1410(100 \%)$ & $13322(100 \%)$ \\
\hline
\end{tabular}

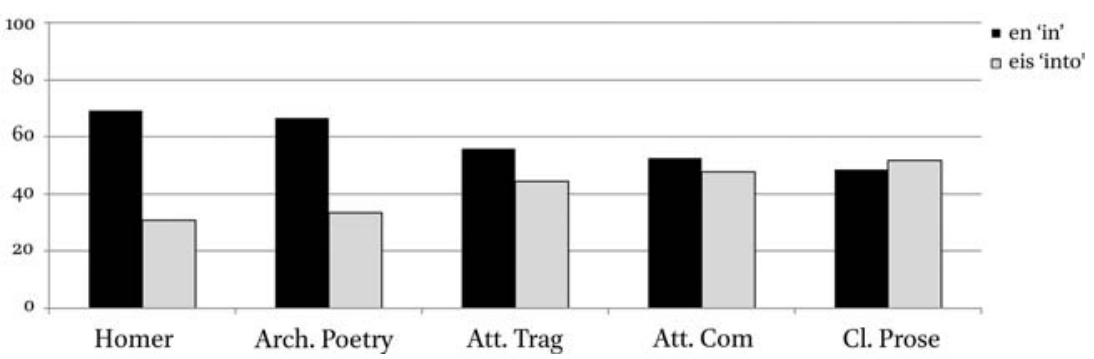

Figure 6. Gradual change in the proportion of dynamic and static encoding

The expansion of directional marking encompasses two general trends: the replacement of the static encoding of goals of motion (the genuine "pregnant" construction), and the increased use of directional prepositional phrases for the encoding of results (see Section 2.3). The two processes were illustrated above with two different types of verb — regular motion verbs taking a goal argument, and change of configuration verbs combining with a result phrase.

More generally, our data suggests that in the 7 th -5 th c., the prepositional system was still undergoing significant changes initiated by an earlier introduction of specialized directional preposition + case combinations.

\subsection{Typological Parallels}

The changes described in this study attest to a gradual shift toward a more consistent satellite-framed system of motion encoding. In particular, Classical Greek relies to a greater extent than Archaic Greek on specialized means of encoding endpoints of motion. By the Classical period, directional preposition + case combinations entirely replace the static alternative in encoding goal arguments of motion verbs. They also become more widespread, compared to earlier stages, in the encoding of results with change of state verbs.

This type of change is not restricted to Ancient Greek but attested, for example, in differences between Old Church Slavonic and Russian, where a similar development appears to affect the same classes of verbs in the same order. Verbs of self-propelled motion are the first verbs to be used exclusively with spe- 
cialized directional expressions, followed by verbs of externally caused motion. Verbs of change of configuration never exclude the static option, even though the frequency of directional encoding increases. Changes in the encoding of endpoints of motion with individual verbs are represented in Tables 9 (for Ancient Greek) and 10 (for Old Church Slavonic and Russian). ${ }^{31}$

Table 9. Changes in the encoding options of individual verbs: Ancient Greek

\begin{tabular}{llcccc}
\hline Verb & Class & Homer & Arch.Lyr & Att.Trag & Cl.Prose \\
\hline baínō 'walk' (as opposed to 'step on') & self-propelled & - & - & - & - \\
thróiskō 'jump' (as opposed to 'attack') & motion & - & - & - & - \\
elaúnō (trans.) 'drive' & & + & + & - & - \\
bállō 'throw, cast' & externally- & + & + & + & - \\
píptō 'fall' & caused motion & + & + & + & - \\
(kath)híemi 'throw (down)' & & + & + & $(+)^{32}$ & - \\
tithénai 'put', histánai 'install, set', etc. & change of & + & + & + & + \\
& configuration & & & & \\
\hline
\end{tabular}

Table 10. Changes in the encoding options of individual verbs: Russian

\begin{tabular}{|c|c|c|c|c|}
\hline Verb & Class & OCS & Old Russian & Russian \\
\hline iziti 'go out', v"ziti 'go in' & self-propelled & + & - & - \\
\hline priiti 'come', priêzditi 'come (by vehicle)' & motion & + & + & - \\
\hline $\begin{array}{l}v^{\prime \prime} z \text { "nesti 'carry up', } v \text { "nesti 'carry in' } \\
\text { mêtati 'throw, cast' } \\
\text { padati, pasti 'fall' }\end{array}$ & $\begin{array}{l}\text { externally- } \\
\text { caused motion }\end{array}$ & + & $\begin{array}{l}+ \\
+ \\
+\end{array}$ & $\begin{array}{l}- \\
- \\
(+)\end{array}$ \\
\hline $\begin{array}{l}\text { polagati, položiti 'put'; postaviti 'set, make } \\
\text { stand'; posaditi 'make sit' }\end{array}$ & $\begin{array}{l}\text { change of } \\
\text { configuration }\end{array}$ & + & + & + \\
\hline
\end{tabular}

The similarities in the way the same change affects different verb classes suggest a common conceptual basis behind the linguistic representation of motion, and attest to the need for a fine-grained semantic analysis in the study of diachronic change. We hope that further research will shed light on the ways in which individual languages and individual verb classes undergo shifts in the dominant motion encoding strategy.

\footnotetext{
31) The table for Old Church Slavonic and Old Russian is compiled based on secondary sources: Toporov 1961; Stanisheva 1966.

32) There is only one occurrence of $($ kath $)$ hiemi with en + dat. in a directional meaning in tragedy, in a metaphorical context (Soph. Ajax 851).
} 


\section{Appendix: A Note on the Relative Chronology of the Iliad and the Odyssey}

The gradual change in the encoding of endpoints of motion provides a hitherto unexplored parameter that is relevant to assessing the relative chronology of the Iliad and the Odyssey. While our conclusions remain largely speculative, due to the small numbers involved, we believe that their potential significance for Greek literary history warrants a full exposition of the evidence.

Turning first of all to the criterion discussed in Section 4.2- the overall proportion of eis 'into' vs. en 'in'-the Odyssey differs significantly from the Iliad (Fisher's test p-value $<$ 0.001), and shows exactly the same proportion as the post-Homeric Archaic corpus (comprising Hesiod, the Homeric Hymns, and Archaic poetry). The difference suggests that the directional preposition eis 'into' - a relatively recent innovation - is more widely used in the Odyssey than in the Iliad, as predicted by the hypothesis of different authorship and a later composition date. ${ }^{33}$

Table A1. The relative frequency of en 'in' vs. eis 'into' in the Iliad and the Odyssey

\begin{tabular}{lrlrrrr}
\hline & Iliad & \multicolumn{3}{c}{ Odyssey } & \multicolumn{2}{c}{ Archaic Poetry } \\
\hline en 'in' & 1105 & $(73 \%)$ & 1005 & $(67 \%)$ & 1156 & $(67 \%)$ \\
eis 'into' & 409 & $(\mathbf{2 7} \%)$ & 488 & $(\mathbf{3 3} \%)$ & 581 & $(\mathbf{3 3 \%})$ \\
Total & 1514 & $(100 \%)$ & 1493 & $(100 \%)$ & 1737 & $(100 \%)$ \\
\hline
\end{tabular}

Some of the individual verbs discussed in this paper are first attested with directional encoding of goals in the Odyssey, and appear in the Iliad exclusively with static prepositional phrases, including, for example, the verbs histèmi 'stand, set' and (kath)hézomai 'sit down'. The verb hístèmi 'stand, set' appears 18 times in the Iliad and 29 times in the Odyssey. In the Odyssey, the only certain example with a directional prepositional phrase occurs with an aorist imperative in 17.447 , whereas in 3 other instances a directional prepositional phrase is ambiguous between an argument of histēmi 'stand, set' and an argument of an accompanying participle of a motion verb. In one of these cases, stê hr' es mésson iòn 'took a stand in the middle by going there' (Od. 8.144), the later established use of histèmi with es mésson 'in the middle' (Hdt.3.62.1, 3.130.1, 3.140.3, Xen. Cyr. 4.1.2) suggests that the prepositional phrase is an argument of the main verb, rather than the participle.

33) This evidence corroborates the data presented in Hagget (1902: 186) on the higher frequency of the use of the accusative with prepositions in the Odyssey as compared to the Iliad (38.21\% vs. $33.84 \%$ of all prepositional phrases); in Herodotus, the frequency increases to $49 \%$ (De Mauro 1960: 228). For a persistent view that the Iliad and the Odyssey are the work of the same poet, cf., for example, López-Ruiz (2012: 325-326). 
The verb (kath)hézomai 'sit down' is attested 5 times in the Iliad and 12 times in the Odyssey; all 4 instances of directional encoding come from the Odyssey.

The verb bállō 'throw, cast' is attested with a directional prepositional phrase 3 times in the Iliad and 5 times in the Odyssey (with 17 and 18 instances of static encoding, respectively), but all 3 examples from the Iliad involve the same prepositional phrase-eis hála 'into the sea' (1.314, 11.495, 11.722), whereas the same preposition + case combination is used with five different noun phrases in the Odyssey.

Table A2 summarizes the distributions for the two texts (the numbers are too small to be statistically significant): ${ }^{34}$

Table A2. Differences between the Iliad and the Odyssey with selected verbs

\begin{tabular}{lccc}
\hline & Iliad & Odyssey & Total \\
\hline $\begin{array}{l}\text { hístēmi 'stand, set' } \\
\text { en + dative }\end{array}$ & 18 & 25 & 43 \\
eis + accusative & 0 & $1(+3 ?)$ & $1(+3 ?)$ \\
$\begin{array}{l}\text { (kath)hézomai 'sit (down)' } \\
\text { en + dative }\end{array}$ & 5 & 8 & 13 \\
eis + accusative & 0 & 4 & 4 \\
bállō 'throw, cast' & & & \\
en + dative & 17 & 18 & 35 \\
eis + accusative & 3 & 5 & 8 \\
$\begin{array}{l}\text { (kath) híemi 'throw (down)' } \\
\text { en + dative }\end{array}$ & 12 & 0 & 12 \\
eis + accusative & 1 & 2 & 3 \\
\hline
\end{tabular}

Examples of static encoding are also restricted to the Iliad in the case of the verbs bainō 'step' (3 times in a formulaic context: ex. 35; 13.618, 16. 503; cf. 6. 65), thrốiskō 'leap, attack' (twice with an object of attack: 5.161, 20.381), and elaúnō 'drive in a weapon in [a part of] one's body' (5.539, 17.519, 20.259, 24.421; an isolated example in later Greek is found in Pindar, Nem. 10.70). Such verbs, however, do not provide conclusive evidence for a difference in use between the Iliad and the Odyssey, since the distribution may depend on the relative prominence of military encounters in the Iliad.

Taken together, these facts are suggestive of a relative prominence of directional marking in the Odyssey, compared to the Iliad. They are consistent with the hypothesis that motion encoding in the Odyssey is innovative, suggesting

\footnotetext{
34) The verb píptō 'fall' does not occur with directional eis + accusative phrases in the Iliad or in the Odyssey. The distribution of tithèmi 'put, place' is not suggestive of any change: Iliad 46 (en) / 5 (eis/es) vs. Odyssey 40 (en) / 1 (eis/es).
} 
in turn that the static encoding of goals was most likely preserved in the poetic language as a relic from the period when there were no specialized directional prepositions. This archaism, however, was apparently not systematically or selfconsciously sought after by later poets, in contrast to tmesis (Haug 2012) and possibly goal accusatives (Létoublon 1985: 20-23; De Boel 1988: 157). ${ }^{35}$ In the encoding of endpoints of motion, the epic diction seems to reflect the changing linguistic practice, marking the distance that separates the Odyssey from the Iliad.

\section{Abbreviations}

$\begin{array}{llll}\text { ACC } & \text { accusative } & \text { NOM } & \text { nominative } \\ \text { AOR } & \text { aorist } & \text { PASS } & \text { passive } \\ \text { ART } & \text { article } & \text { PERF } & \text { perfect } \\ \text { DAT } & \text { dative } & \text { PL } & \text { plural } \\ \text { DIR } & \text { directional adverb } & \text { PLPERF } & \text { pluperfect } \\ \text { FUT } & \text { future } & \text { PRES } & \text { present } \\ \text { GEN } & \text { genitive } & \text { PRT } & \text { particle } \\ \text { IMPER } & \text { imperative } & \text { PREP } & \text { prepositional case } \\ \text { IMPF } & \text { imperfective } & \text { PTCP } & \text { participle } \\ \text { INF } & \text { infinitive } & \text { SG } & \text { singular } \\ \text { MID } & \text { middle } & \text { SUBJ } & \text { subjunctive } \\ \text { MP } & \text { medio-passive } & & \end{array}$

\section{References}

Beavers, John, Beth Levin and Shiao Wei Tham. 2010. The typology of motion expressions revisited. Journal of Linguistics 46: $331-377$.

Bortone, Pietro. 2010. Greek Prepositions: From Antiquity to the Present. Oxford: Oxford University Press.

Chantraine, Pierre. 1927. Histoire du parfait grec. Paris: Librairie Ancienne Honoré Champion.

Chantraine, Pierre. 1963. Grammaire homérique. Vol. 2: Syntaxe. Paris: Klincksieck.

Cooper, Guy L. 1998. Attic Greek Prose Syntax, after K.W. Krüger. Vol. 2. Ann Arbor: University of Michigan Press.

Cunliffe, Richard J. 1963. A Lexicon of the Homeric Dialect. Norman, OK: University of Oklahoma Press.

Dahl, Östen. 1987. Case grammar and prototypes. In René Dirven and Günter Radden (Eds.), Concepts of Case, 147-161. Tübingen: Gunter Narr.

De Boel, Gunnar. 1988. Goal Accusative and Object Accusative in Homer: A Contribution to the Theory of Transitivity. Brussels: Paleis der Academiën.

35) De Boel believes that the increased use of goal accusatives within the poetic corpus suggests that the feature was "artificial" to begin with. As Haug's diachronic study of tmesis demonstrates, this need not be the case. 
De Mauro, Tullio. 196o. Frequenza e funzione dell'accusativo in Greco. Accademia nazionale dei Lincei. Rendiconti della classe di scienze morali, storiche e filologiche. Serie 8, fasc. 5-6: 209230.

Delbrück, Berthold. 1879. Die Grundlagen der griechischen Syntax. Halle: Verlag der Buchhandlung des Waisenhauses.

Faraone, Christopher A. Forthc. Did the Chryses episode in Iliad 1 begin its life as a separate Homeric Hymn? In Ilya Kliger and Boris Maslov (Eds.), Persistent Forms: Explorations in Historical Poetics.

Fong, Vivienne. 1997. The order of things: What directional locatives denote. Ph.D. diss., Stanford University.

García-Ramón, José Luis. 1995. Zum Akkusativ der Richtung im Vedischen und im Indogermanischen. In Heinrich Hettrich et al. (Eds.), Verba et structurae, pp. 33-51. Innsbruck: Institut für Sprachwissenschaft der Universität.

Gerö, Eva-Carin and Arnim von Stechow. 2003. Tense in time: The Greek perfect. In Regine Eckardt et al. (Eds.), Words in Time: Diachronic Semantics from Different Points of View, 251-293. Berlin: de Gruyter.

Hagget, A.S. 1902. On the uses of the prepositions in Homer. In Studies in Honor of Basil L. Gildersleeve, 181-187. Baltimore: The Johns Hopkins Press.

Haug, Dag. 2008. From resultatives to anteriors in Ancient Greek: On the role of paradigmaticity in semantic change. In Thórhallur Eythórsson (Ed.), Grammatical Change and Linguistic Theory: The Rosendal papers, 285-305. Amsterdam: John Benjamins.

Haug, Dag T.T. 2012. Tmesis in the epic tradition. In Øivind Andersen and Dag T.T. Haug (Eds.), Relative Chronology in Early Greek Epic Poetry, 96-105. Cambridge: Cambridge University Press.

Hewson, John and Vit Bubenik. 20o6. From Case to Adposition: The Development of Configurational Syntax in Indo-European Languages. Amsterdam: John Benjamins.

Horrocks, Geoffrey C. 1981. Space and Time in Homer: Prepositional and Adverbial Particles in the Greek Epic. New York: Arno Press.

Kühner, Raphael and Bernhard Gerth. 1898. Ausführliche Grammatik der griechischen Sprache. 2. Teil: Satzlehre. Vol. 1. Hannover: Hahnsche Buchhandlung.

Létoublon, Françoise. 1980. Le vocabulaire de la supplication en grec: performatif et dérivation délocutive. Lingua 52: 325-336.

Létoublon, Françoise. 1985. Il allait, pareil à la nuit. Les verbes de mouvement en grec: supplétisme et aspect verbal. Paris: Klincksieck.

LSJ = A Greek-English Lexicon. Compiled by Henry G. Liddell and Robert Scott, augmented by Henry S. Jones. Oxford: Oxford University Press, 1996.

López-Ruiz, Carolina. 2012. Review of M.L. West. The Making of the Iliad (Oxford, 2011). American Journal of Philology 133.2: 323-326.

Luraghi, Silvia. 2003. On the Meaning of Prepositions and Cases: The Expression of Semantic Roles in Ancient Greek. Amsterdam: John Benjamins.

Maslov, Boris and Tatiana Nikitina. 2009. De constructione Graeca quae 'praegnans' appellatur. Indoevropejskoe jazykoznanie i klassičeskaja filologija 13: 421-424.

Meillet, Antoine and Joseph Vendryes. 1953. Traité de grammaire comparée des langues classiques. 2nd ed. Paris: Librairie Ancienne Honoré Champion.

Meier-Brügger, Michael. 2003. Indo-European Linguistics. With contributions by Matthias Fritz and Manfred Mayrhofer. Berlin: Walter de Gruyter.

Monro, David B. 1891. A Grammar of the Homeric Grammar. Oxford: Clarendon.

Moore, Ralph W. 1934. Comparative Greek and Latin Syntax. London. Republished in 1999 by Bristol Classical Press.

Morpurgo Davies, Anna. 1964. 'Doric' features in the language of Hesiod. Glotta 42: 138165.

Nikitina, Tatiana. 2008. Pragmatic factors and variation in the expression of spatial goals: The 
case of into vs. in. In Anna Asbury et al. (Eds.), Syntax and Semantics of Spatial P, 175-195. Amsterdam: John Benjamins.

Nikitina, Tatiana. 2009. Subcategorization pattern and lexical meaning of motion verbs: A study of the Source/Goal ambiguity. Linguistics 47: 1113-1141.

Nikitina, Tatiana. 2010. Variation in the encoding of endpoints of motion in Russian. In Renee Perelmutter and Viktoria Driagina-Hasko (Eds.), New Approaches to Slavic Verbs of Motion, 267-290. Amsterdam: John Benjamins.

Nikitina, Tatiana. Forthc. The many ways to find the "right" and the "left": On dynamic projection models in the encoding of spatial relations. To appear in Proceedings of the 38 th Annual Meeting of the Berkeley Linguistics Society.

Poppo, Ernst F. 1889. Thucydidis De bello peloponnesiaco libri octo. 3 rd ed. rev. by Matthias Stahl. Vol. 1(2). Leipzig: B.G. Teubner.

Ruijgh, Cornelis J. 1994. La préposition è $\pi$ í. Valeurs sémantiques et choix des cas. In Bernard Jacquinod (Ed.), Cas et prépositions en Grec Ancien: Contraintes syntaxiques et interprétations sémantiques, 133-148. Saint-Étienne: Publications de l' Université de Saint-Etienne.

Schwyzer, Eduard. 1950. Griechische Grammatik. Vol. 2: Syntax und syntaktische Stilistik. Completed and edited by A. Debrunner. Munich: C.H. Beck.

Skopeteas, Stavros. 2008a. Grammaticalization and sets of form-function pairs: Encoding spatial concepts in Greek. In Elisabeth Verhoeven et al. (Eds.), Studies in Grammaticalization, 25-56. Berlin: Mouton de Gruyter.

Skopeteas, Stavros. 2008b. Encoding spatial relations: Language typology and diachronic change in Greek. STUF 61(1): 54-66.

Slobin, Dan I. 1996. Two ways to travel: Verbs of motion in English and Spanish. In Masayoshi Shibatani and Sandra A. Thompson (Eds.), Grammatical Constructions: Their Form and Meaning, 195-220. Oxford: Clarendon Press.

Smyth, Herbert Weir. 1956. Greek Grammar. Rev. by G.M. Messing. Cambridge, MA: Harvard University Press.

Stanisheva, Dina S. 1966. Vinitel'nyj padežv vostočnoslavjanskix jazykax. Sophia: Bolgarskaja Akad. Nauk.

Talmy, Leonard. 1985. Lexicalization patterns: Semantic structure in lexical forms. In Timothy Shopen (Ed.), Language Typology and Syntactic Description, Vol. 3, 57-149. Cambridge: Cambridge University Press.

Talmy, Leonard. 2000. Toward a Cognitive Semantics, Vol. 2: Typology and Process in Concept Structuring. Cambridge, MA: MIT Press.

Toporov, Vladimir N. 1961. Lokativ v slavjanskix jazykax. Moscow: Akademija Nauk SSSR.

Wackernagel, Jacob. 2009 [1928]. Lectures on Syntax: with special reference to Greek, Latin, and Germanic, edited with notes and bibliography by David Langslow. Oxford: Oxford University Press.

Willems, Klaas. 2011. The semantics of variable case marking (Accusative/Dative) after two-way prepositions in German locative constructions. Towards a constructionist approach. Indogermanische Forschungen 116: 324-366. 